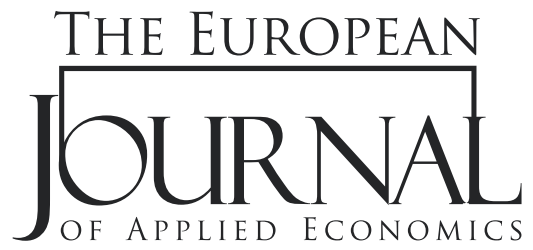

\title{
INFRASTRUCTURE DEVELOPMENT, INSTITUTIONS, AND INTRA-REGIONAL TRADE: THE CASE OF EAST AFRICA
}

\author{
James Ochieng*, Daniel Abala, Mary Mbithi
}

School of Economics, University of Nairobi, Kenya

\begin{abstract}
:
This study empirically examines the relationship between infrastructure stock and bilateral trade flows using a panel of 11 countries in East Africa for the period 2000 to 2018. Infrastructure augmented gravity model was estimated using total bilateral exports for the countries in East Africa. Infrastructure was disaggregated into transport and information and communications technology (ICT) infrastructures. Two institutional variables, control of corruption index and regulatory quality, were incorporated in the model. By employing Poisson Pseudo Maximum Likelihood (PPML) estimator, the results confirm that both ICT and transport infrastructures and quality institutions positively impact on the volumes of total bilateral exports in East Africa. However, ICT infrastructure has a greater impact on trade flows compared to transport infrastructure. Therefore, more resources should be channelled towards increasing the stock of ICT infrastructure to propel trade and regional integration in East Africa.
\end{abstract}

\section{Article info:}

Received: May 27, 2020

Correction: July 31, 2020

Accepted: September 7, 2020

\section{Keywords:}

Infrastructure Stock, Institutional Quality, Intra-regional Trade, East Africa.

\section{JEL Classification:}

H54, F10, F15

\section{INTRODUCTION}

The successful participation of countries in international trade is determined by a number of factors other than the level of tariffs and other quantitative trade restrictions. These other factors include the quantity and quality of the existing infrastructure. Infrastructure development promotes competitiveness by reducing trade costs and consequently enhancing regional economic integration (Limao and Venables, 2001; Behar and Venables, 2011). Therefore, infrastructure development enables an economy to exploit a comparative advantage, specifically in trade and that infrastructure deficiency limits international trade (Cosar and Demir, 2016; Danaubauer at al., 2018). 
Infrastructure development accelerates the pace of economic progress by enhancing more production activities, and leads to lower costs for conducting domestic and foreign trade. More infrastructure facilities lead to industrialization and many employment opportunities are created, which leads to poverty reduction in a country (Sahoo et al., 2010). Various kinds of infrastructure facilitate international trade; hard infrastructure is essential for trade between a country and the rest of the world. They include roads, rail lines, ports, and airports. Soft infrastructure also determines trade volumes, it relates to cost, time, and the number of documents needed during trade between the borders (UNCTAD, 2013). The quality of infrastructure $^{1}$ in a country determines costs and volume of international trade. Furthermore, since various sectors consume infrastructure services differently, infrastructure quality affects opportunity cost and specialization in international trade (World Trade Organization, 2004).

The cost of trade is a key concern to many developing countries, like those in the East Africa region. According to the World Trade Organization (2015), trade costs were 227 percent (of their ad-valorem tax equivalent) in less developed countries (LDCs) for the manufacturing sector, compared with 125 percent, 98 percent, and 82 percent in lower middle income, upper middle income and high-income countries respectively. These figures show that infrastructure in LDCs accounts for a high percentage of trade costs in comparison to the developed countries.

The East Africa region has been implementing joint infrastructure programs in roads, railway, pipeline, ports, and in energy development. For example, some of the joint infrastructure projects in East Africa are spearheaded by the East African Community (EAC) Partner States. Under the transport sector, there are: two main transport corridors to facilitate in the region; the first is the northern corridor, which covers $1700 \mathrm{~km}$ from Mombasa port and serves Kenya, Rwanda, Burundi, Uganda, South Sudan, and Eastern DRC; the second is the central corridor, which covers 1,300 km from the port of Dar es Salaam, and serves Tanzania, Rwanda, Burundi, Uganda, Eastern DRC, and Zambia. Apart from the road infrastructure, railway infrastructure is also given consideration; this includes upgrading of existing railway tracks to Standard Gauge Railway. The EAC railway project has been planned to cover the northern corridor, from Mombasa to Malaba, then to Juba and Kigali, and finally to Bujumbura. In terms of communication infrastructure, under the EAC Broadband Information and Communications Technology (ICT) Infrastructure Network (EAC-BIN), the EAC has managed to increase the ICT infrastructure through four undersea cables, which covers the East African Coast: EASSY, SEACOM, TEAMS and LION 2 (EAC, 2011a). All these are intended to promote both intra-and inter regional trade by removing impediments in the movement of goods and services (EAC, 2011b).

The performance of the East Africa region in international trade remains poor, notwithstanding the increased infrastructure projects in the region. For example, only 6 percent of total imports for the EAC Partner States are sourced from the region, while exports to the region account for only 20 percent of the total (World Trade Organization, 2019). The poor performance of trade in East Africa is partially attributed to technical barriers to trade, lack of product diversification, and a lack of a common currency. However, it is difficult to understand the trade performance of the East Africa region without understanding the contributions of infrastructure and quality of institutions. According to Francois and Manchin (2013), better institutions can promote trade. In general, the volume of trade and the ability of low-income countries to participate in international trade depends on institutional quality and access to a well-developed infrastructure.

1 Infrastructure quality is determined based on an index that describes the extent of infrastructure development in a country. From the World Economic Forum, a value of 1 refers to an extremely underdeveloped infrastructure, while a value of 7 refers to an infrastructure that is extensive and efficient by international standards. 
The role of infrastructure on regional trade flows has been investigated in a number of previous studies (Ismail and Mahyideen, 2015; Shepherd, 2016; Raychaudhuri and De, 2016; Rehman et al., 2020). However, there is little understanding of how different forms of infrastructure and institutions affect intra-regional trade flows, particularly in East Africa. Therefore, this paper explores the impact of transport and ICT infrastructures on East Africa's trade by incorporating quality of institutions as an element of the analysis using the Posisson-Pseudo Maximum Likelihood (PPML) estimator. The superiority of PPML in estimating trade flows is that it performs well in the presence of zero bilateral trade flows, and controls for different patterns of heteroscedasticity in the regression model (Silva and Tenreyro, 2011).

The rest of the paper is organized as follows: Section 2 discusses the literature on infrastructure and trade, while Section 3 presents the methodology and data pertaining to this study. Section 4 discusses the study findings, while conclusions and policy implications are presented in Section 5.

\section{LITERATURE}

Even though effort has been made worldwide to reduce tariffs, a number of trade barriers still prevail. Such barriers are classified as either 'soft' or 'hard' (De, 2006). Trade facilitation measures are always used to overcome the soft barriers; on the other hand, hard barriers are linked to infrastructure, and are minimized by measures related to transport facilitation.

Gravity model was first augmented to include infrastructure variables by Bougheas et al. (1999), by extending the Dornbusch-Fischer-Samuelson model of 1997 in a study of infrastructure and trade from a sample of European countries. The authors linked the variations in trade volumes and competitiveness across countries to disparities that exist in the stock and quality of infrastructure across regions. Furthermore, they gave evidence that infrastructure development has the potential of increasing trade flows, as it acts by lowering trade costs. Celbis et al. (2014), in concurrence with these findings, argue that infrastructure development lowers transport costs, thereby increasing a country's trade volume. They state that transport infrastructure is important to lowering trade related costs, especially during the transportation of goods.

Market expansion is also realized with improved infrastructure, and with consumers being exposed to many competing producers, prices fall, resulting in welfare improvement (Henckel and McKibbin, 2010). Other studies that support the crucial role of infrastructure in promoting trade by lowering trade costs are Francois and Manchin (2013), Raychaudhuri and De (2016), and Bonfatti and Poelhekke (2017). They argue that developing the physical infrastructure plays an important role in lowering trade costs and, consequently, in increasing the volume of trade. The role of infrastructure in lowering trade costs and increasing international trade flows is also supported by Donaubauer et al. (2018), who employed a gravity model for a panel of 150 developed and emerging countries using data for the period 1992 and 2011. They found that improving infrastructure is important for reducing not only bilateral trade costs, but also multilateral trade costs. Moreover, a study by de Soyres et a.l (2018) established that countries located along the infrastructure corridors under Belt and Road Initiative experience the most gains in terms of time and trade costs, that decline by up to 11.9 percent and 10.2 percent, respectively.

Using a sample of 10 economies from Asia, Ismail and Mahyideen (2015) investigated the effect of infrastructure on trade by applying a gravity model augmented for various infrastructure types. Using data for the period 2003 to 2013 and estimating a random effects model, they established that improved transport infrastructure increases the volume of trade. Rehman et al. (2020) obtained similar results for 
6 South Asian countries by employing a pooled mean group estimator between 1990 and 2017. Shepherd (2016) employed network analysis methods to examine the link between infrastructure development, global value chains, and trade facilitation performance for 44 countries in Sub-Saharan Africa (SSA). The study established that SSA is marginalized in world networks for value added trade and global value chains due to high trade costs resulting from inadequate infrastructure.

Other panel studies that support the importance of infrastructure in promoting growth of trade include Hernandez and Taningco (2010), who applied gravity model and import data for 11 Asian economies for the period 2006 to 2008. They used a fixed effects model and found trade in industrial supplies, petroleum products, consumption, and investment goods in East Asia as being dependent quality of port infrastructure. Shepherd and Wilson (2009) used a gravity model using data for 14 ASEAN member countries for the period 2000 to 2005 . They employed ordinary least squares estimator and found transport and ICT infrastructure as the main facilitators of trade in Southeast Asia. Studies by Bankole et al. (2013), Yushkova (2014), and Xing (2015) also support the role of ICT infrastructure in enhancing bilateral trade.

By examining the effect of physical infrastructure, ICT, border and transport efficiency on performance of exports of 101 developing countries for the period 2004 to 2007, Portugal-Perez and Wilson (2012) employed two-stage a Heckman selection model and established that exports are mainly driven by physical infrastructure. However, they established a declining effect of physical infrastructure as income rises, as well as ICT and border/transport efficiency. In a natural experiment to assess the effects of domestic transport infrastructure on Chile's trade flows, Martincus and Blyde (2013) combined firmlevel data between 2008 to 2011 and used a difference in difference estimator to establish that shocks to domestic infrastructure negatively influence firms' exports. Similarly, to support the crucial role of transport infrastructure in trade facilitation, Francois and Manchin (2013) established that transport and communication infrastructure and quality of institutions are important determinants of both a country's export volume and possibility of exports. Alvarez et al. (2018) support the crucial role of institutions in bilateral trade but argue that the effect of institutions on bilateral trade is somewhat lower than other determinants such as distance. Other studies by Yu et al (2015) and Lin and Fu (2016) also support the role of institutions in fostering international trade.

Studies by Behar and Manners (2008), Djankov et al. (2006) and Bensassi et al. (2015) have found that the volume of trade increases through a reduction in trade costs, resulting from development of physical infrastructure and improvement in logistics. In a similar study, Fink et al. (2005) used a gravity model to investigate the effects of communication cost on bilateral trade. They found that cost of phone calls is an important determinant of bilateral trade. They found that a reduction in the cost of phone calls by 10 percent leads to an increase in the volume of bilateral trade by 8 percent. To emphasize the link between infrastructure, transport costs and trade, Limao and Venables (2001) estimated a gravity model for imports using data for 103 countries for the year 1990. By employing a tobit and fixed effects models, they established that distribution of infrastructure from the median to the top 25th percentile increases the volume of trade by 68 percent.

Nordas and Piermartini (2004) built an index of infrastructure quality using road, airport, port, and telecommunications and time required for customs clearance as measures of infrastructure. They employed a gravity model for 138 countries using exports data for different sectors. Using ordinary least squares and fixed effects estimators, they investigated how infrastructure quality affects trade, and found that poor quality of infrastructure increases the entire transactions costs as goods are likely to be damaged during transportation. 


\section{METHODOLOGY}

\section{Gravity Model}

Following literature, this study employed an augmented gravity model to analyze the impact of infrastructure development and institutions on trade. Gravity model is considered to be the most robust partial equilibrium model in explaining the variations in bilateral trade flows (De, 2006). Gravity model was first introduced by Tinbergen (1962), and later modified by Anderson (1979) to include trade costs under the assumption that each country produces a unique product, which applies the concept of product differentiation. The model was further modified by Anderson and Van Wincoop (2003) to capture 'multilateral resistance terms.' The Newton's law of gravity is given as:

$$
\mathrm{F}=\mathrm{k} \frac{\mathrm{N}_{1} \mathrm{~N}_{2}}{\mathrm{D}^{2}}
$$

Where $F$ - is the gravitational force between the two objects, $N_{1}$ and $N_{2}$ are the respective masses, $D$-is the distance between the centres of the masses, and $k$ - is a constant.

The gravity model of trade states that the volume of trade between two countries varies directly with the product of two countries' GDP and indirectly with distance between their capital cities. The model is formulated as:

$$
\mathrm{T}_{\mathrm{ij}}=\mathrm{kG}_{\mathrm{i}}^{\beta} \mathrm{G}_{\mathrm{j}}^{\gamma} \mathrm{D}_{\mathrm{ij}}^{\delta}
$$

where $T_{i j}$ - is trade flow, such as exports from country $i$ to country $j, k$ - is a constant term, $G_{i}$ and $\boldsymbol{G}_{j}$ - are GDPs of country $\boldsymbol{i}$ and $\boldsymbol{j}$ (which are proxies of the size of each trading country) and $\boldsymbol{D}_{i j}$-is distance between capital city $\boldsymbol{i}$ and $\boldsymbol{j}$. Equation (2) therefore states that trade between country $\boldsymbol{i}$ and $\boldsymbol{j}$ is directly proportional to the GDP of both exporting and importing countries and inversely proportional to the distance between them. Evidence suggest country size and geographical distance (which captures trade costs) as the most important determinants of bilateral exports between countries.

Following Anderson and Van Wincoop (2003), gravity model was modified to include multilateral trade resistance variables. To include multilateral resistance terms, gravity model is augmented using 'exporter and importer fixed effects' to come up with an equation of the form:

$$
\mathrm{TR}_{\mathrm{ij}}=\mathrm{k} Y_{\mathrm{i}}^{\beta} \mathrm{Y}_{\mathrm{j}}^{\gamma} \mathrm{D}_{\mathrm{ij}}^{\delta} \mathcal{E}^{\theta_{\mathrm{ij}}+\mathrm{\theta}_{\mathrm{j} \sigma j}}
$$

Where $\sigma_{\mathrm{i}}$ and $\sigma_{j}$ are exporter and importer dummies and $\mathcal{\varepsilon}$ - is the error term.

Equation (3) therefore, captures the multilateral trade resistance terms. The gravity model can be augmented to include other factors, such as infrastructure and trade facilitation measures, which are important determinants of trade costs and volume. Gravity model, therefore, gives the key link between trade flows and associated barriers.

Equation (2) is non-linear in parameters, by linearizing equation (2), equation (4) is obtained:

$$
\operatorname{Ln}\left(T_{i j}\right)=\alpha+\beta \operatorname{In}\left(G_{i}\right)+\gamma \operatorname{In}\left(G_{j}\right)+\delta \operatorname{In}\left(D_{i j}\right)
$$


Where $\ln$ is the natural logarithm

Equation (4) is the simple (baseline) gravity model and can be estimated as it is. However, there are other determinants of volume of trade such as infrastructure, institutional variables, language, foreign direct investments (FDI), inflation, exchange rates, etc. Therefore, the model is augmented to include such variables to assess their impact on trade flows.

The log-linear version of the augmented gravity equation is given as:

$$
\begin{aligned}
\ln E X_{i, j t}=\beta_{0} & +\beta_{1} \ln G D P_{i t}+\beta_{2} \ln G D P_{j+t}+\beta_{3} \ln D_{i, j}+\beta_{i} \ln P O P_{i t}+\beta_{5} \ln P O P_{j, t} \\
& +\beta_{6} \ln I C T_{i t}+\beta_{7} \ln I C T_{j, t}+\beta_{8} \ln T R A N_{i t}+\beta_{9} \ln T R A N_{j, t}+\beta_{10} E R_{i t} \\
& +\beta_{11} F D I_{i t}+\beta_{12} C I_{i t}+\beta_{13} C I_{j, t}+\beta_{14} R E G Q_{i t}+\beta_{15} R E G Q_{j t}+\beta_{16} E A C \\
& +\beta_{17} W T O+\beta_{18} L A N G_{i t}+\beta_{19} E T H_{i j}+\beta_{20} C O N T_{i, j}+\varepsilon_{i, j}
\end{aligned}
$$

Where

$E X_{i, j, t}$-Total exports from $i^{\text {th }}$ Partner State to the $j^{\text {th }}$ Partner State (importing country) at a given time, $t$; $G D P$ represents gross domestic product; $D$ stands for distance between capitals of trading partners; $P O P$ refers to population; ICT represents ICT infrastructure index; TRAN represents transport infrastructure index; ER stands for official exchange rate per dollar US dollar, FDI stands for net foreign direct investment inflows; $C I$ stands for control of corruption index; REGQ stands for regulatory quality; $E A C$ refers to free trade agreements dummy under the East African Community (EAC) customs union, with 1 = member of EAC, 0 -otherwise; WTO refers to membership of World Trade Organization (WTO), with $1=$ member of WTO, 0 -otherwise; $L A N G$ represents official language dummy, with $1=$ same official language in country $\boldsymbol{i}$ and $\boldsymbol{j}, 0$-otherwise, $E T H$ refers to ethnic language, with $1=$ ethnic language spoken by at least 9 percent of population in country $i$ and $j$, CONT refers to contiguity, with $1=$ common border between country $\boldsymbol{i}$ and $\boldsymbol{j}, 0$ otherwise and $\boldsymbol{\varepsilon}_{i, t}-$ is the error term.

Estimation of the logarithmic transformation of the gravity model poses a challenge when there are zero trade flows since the logarithm of zero is not defined. Estimation of such a model using ordinary least squares produces inconsistent and biased estimates, which do not vanish with increase in sample size (Silva and Tenreyro, 2011). Therefore, the choice of estimation was based on PPML estimator by Silva and Tenreyro (2006). PPML is important in the estimation of the gravity equation because it accounts for zero bilateral trade flows between trading partners and performs well in the presence of heteroscedasticity. The final estimated model corresponds to taking the conditional expectations form of (5):

$$
\begin{aligned}
& E X_{i, j, t}=\exp \left[\ln \beta_{0}+\beta_{1} \ln G D P_{i, t}+\beta_{2} \ln G D P_{j, t}+\beta_{3} \ln D_{i, j}+\beta_{4} \ln P O P_{i t,}+\beta_{5} \ln P O P_{j, t}\right. \\
& +\beta_{6} \ln I C T_{i t,}+\beta_{7} \ln I C T_{j, t}+\beta_{s} \ln T R A N_{i t}+\beta_{9} \ln T R A N_{j: t}+\beta_{10} E R_{i t} \\
& +\beta_{11} F D I_{i t}+\beta_{12} C I_{i t}+\beta_{13} C I_{j t}+\beta_{14} R E G Q_{i t}+\beta_{15} R E G Q_{j t}+\beta_{16} E A C \\
& \left.+\beta_{17} W T O+\beta_{18} L A N G_{i, t}+\beta_{19} E T H_{i, j}+\beta_{20} C O N T_{i t}\right]+\varepsilon_{i t}
\end{aligned}
$$

Equation (6) was estimated using the PPML estimation technique. 


\section{Data and Sources}

This study investigates the effect of infrastructure development and institutions on bilateral trade in East Africa for the period 2000 to 2018. The countries included in the study are presented in Table A1 in the appendix. Bilateral exports are measured in current US dollars and obtained from World Bank's World Integrated Trade Solution (WITS) database. GDP is measured at current US \$ and obtained from World Development Indicators (WDI) of the World Bank; distance between the capital cities in East Africa is obtained from CEPII database. Transport and ICT infrastructure stock were obtained from African Development Bank (AfDB) Socio-Economic database ${ }^{2}$. Data on other macro variables, such as population, foreign direct investments, and exchange rate, were obtained from WDI. Data on control of corruption index and regulatory quality, used as indicators for institutional quality, was obtained from Worldwide Governance Indicators of the World Bank. Data on WTO trade agreements dummy, official and ethnic language dummies were obtained from the CEPII database, while EAC free trade agreements dummy was based on author's elaboration.

\section{RESULTS AND DISCUSSION}

The summary statistics for the variables used in the gravity is presented in Table $\mathrm{C} 1$ in Appendix C. Table 1 presents the findings of the general gravity model for East Africa. It includes both transport infrastructure, ICT infrastructure, and other control variables, such as quality of institutions.

Table 1: Effect of ICT and Transport Infrastructure on East Africa's Trade

\begin{tabular}{|c|c|c|}
\hline \multicolumn{2}{|c|}{ Dependent Variable: Exports } & \multirow{2}{*}{$\begin{array}{c}\text { Method: PPML } \\
(2) \\
\end{array}$} \\
\hline Variable & $(1)$ & \\
\hline \multirow{2}{*}{$\log$ of $G D P_{i}$} & $0.462^{* * *}$ & $0.199^{* *}$ \\
\hline & $(0.104)$ & $(0.095)$ \\
\hline \multirow{2}{*}{$\log$ of $G D P_{j}$} & $0.835^{\star *}$ & $0.735^{\star}$ \\
\hline & $(0.409)$ & $(0.431)$ \\
\hline \multirow{2}{*}{ Log of Distance } & $-0.462^{\star *}$ & $-0.523^{\star *}$ \\
\hline & $(0.188)$ & $(0.202)$ \\
\hline \multirow{2}{*}{ Log of Population } & $1.196^{* * *}$ & $1.246^{\star * *}$ \\
\hline & $(0.259)$ & $(0.263)$ \\
\hline \multirow{2}{*}{ Log of Population } & $0.507^{\star * *}$ & $0.531^{\star * *}$ \\
\hline & $(0.062)$ & $(0.070)$ \\
\hline \multirow{2}{*}{ ICT Infrastructure ${ }_{i}$} & $0.647^{\star * *}$ & $0.558^{\star *}$ \\
\hline & $(0.225)$ & $(0.246)$ \\
\hline \multirow{2}{*}{ ICT Infrastructure $_{j}$} & $0.051^{\star *}$ & $0.065^{\star * *}$ \\
\hline & $(0.369)$ & $(0.018)$ \\
\hline \multirow{2}{*}{ Transport Infrastructure $_{i}$} & -0.175 & 0.111 \\
\hline & $(0.144)$ & $(0.139)$ \\
\hline \multirow{2}{*}{ Transport Infrastructure $_{j}$} & $-0.096^{* * *}$ & $0.097^{\star * *}$ \\
\hline & $(0.012)$ & $(0.014)$ \\
\hline \multirow{2}{*}{${\text { Exchange } \text { Rate }_{i}}$} & $-0.185^{\star * *}$ & $-0.206^{\star * *}$ \\
\hline & $(0.032)$ & $(0.206)$ \\
\hline
\end{tabular}

2 See Appendix B for the measurements and methodology employed in constructing the infrastructure composite index. 


\begin{tabular}{|c|c|c|}
\hline Log of Foreign Direct Investment ${ }_{i}$ & $\begin{array}{c}-0.097^{\star *} \\
(0.045)\end{array}$ & $\begin{array}{c}-0.031 \\
(0.032)\end{array}$ \\
\hline EAC Trade Agreements & $\begin{array}{c}0.452^{\star * *} \\
(0.144)\end{array}$ & $\begin{array}{c}0.559^{* * *} \\
(0.133)\end{array}$ \\
\hline WTO Trade Agreements & $\begin{array}{c}0.684^{\star * *} \\
(0.230)\end{array}$ & $\begin{array}{c}0.768^{* * *} \\
(0.281)\end{array}$ \\
\hline Official Language & $\begin{array}{l}-0.083 \\
(0.195)\end{array}$ & $\begin{array}{c}-0.068 \\
(0.222)\end{array}$ \\
\hline Ethnic Language & $\begin{array}{c}0.662^{* * *} \\
(0.167)\end{array}$ & $\begin{array}{c}0.609 \\
(0.172)\end{array}$ \\
\hline Contiguity & $\begin{array}{c}0.815^{\star * *} \\
(0.131)\end{array}$ & $\begin{array}{c}0.775^{\star * *} \\
(0.133)\end{array}$ \\
\hline Corruption Index ${ }_{i}$ & $\begin{array}{l}0.416^{* *} \\
(0.171)\end{array}$ & \\
\hline Corruption Index $x_{j}$ & $\begin{array}{l}0.819^{*} \\
(0.472)\end{array}$ & \\
\hline Regulatory Quality & & $\begin{array}{l}0.583^{\star *} \\
(0.283)\end{array}$ \\
\hline Regulatory Quality & & $\begin{array}{l}-0.039 \\
(0.193)\end{array}$ \\
\hline Constant & $\begin{array}{c}-25.594^{* * *} \\
(2.612)\end{array}$ & $\begin{array}{c}-21.631^{\star \star \star} \\
(2.322)\end{array}$ \\
\hline Psuedo Log-likelihood & -1123412 & -1142363 \\
\hline$R^{2}$ & 0.7987 & 0.8041 \\
\hline Observations & 890 & 890 \\
\hline
\end{tabular}

${ }^{*} P<0.10,{ }^{*} P<0.05,{ }^{* * *} P<0.01 ;$ Robust standard errors are in parentheses, $\boldsymbol{i}$ and $\boldsymbol{j}$ are exporting and importing countries respectively

The role of ICT infrastructure in globalization cannot be underestimated, as it lowers communication costs and simplifies the custom procedures, resulting in more trade. Increasing the stock of ICT infrastructure would increase bilateral exports among the countries in East Africa. Increasing the stock of exporting country's ICT infrastructure significantly increases bilateral exports within East Africa. Similarly, the destination country's ICT infrastructure is also crucial for trade. If the stock of exporting country's ICT infrastructure increases by 10 percent, bilateral exports would increase by about 6.0 percent. This implies that a higher stock of ICT infrastructure is associated with more exports in the East African region. Although both exporter and importer countries infrastructure promote trade, the exporting country's infrastructure has a somewhat larger impact. The results support the findings by Francois and Manchin (2013), Portugal-Perez and Wilson (2012), who established that ICT infrastructure is important for increasing exports. Generally, ICT infrastructure is important, as it enhances efficiency, hence increasing volume of exports and trade in general.

The results also reveal that increasing the stock of transport infrastructure of the importing country has a greater potential for increasing the volume of exports in East Africa. At 5 percent level of significance, increasing the stock of the importing country's transport infrastructure by 10 percent would increase in intra-East Africa exports by about 1.0 percent. The impact of the exporting country's 
transport infrastructure has a positive, but not statistically significant, impact on exports. In general, it is expected that infrastructure development would promote trade by lowering transport costs. High transport costs hinder bilateral trade. The findings are similar to those of Limao and Venables (2001), Clark et al. (2004), Shepherd and Wilson (2009), Behar and Manners (2008), Francois and Manchin (2013) and Celbis et al., (2014). Infrastructure development leads to lower transport costs, hence an increased value of exports. The findings support the idea that the destination country's infrastructure, and even the state of infrastructure in the transit countries, have strategic roles in bilateral trade (Limao and Venables, 2001).

Quality of institutions is an important determinant of trade flows. The findings reveal that improvement in the regulatory of the exporting country has positive significant effect of bilateral exports. Similarly, the findings reveal that control of corruption of the exporting country is important for bilateral trade. An improvement in control of corruption index would promote bilateral exports among the countries in the East African region.

The coefficient of EAC free trade agreements is positive and statistically significant at 1 percent level of significance. It implies that EAC Partner States are 1.6 times $^{3}$ more likely to trade among themselves due to the regional trade agreements than with non-EAC members. Free trade agreements minimize the usual barriers associated with trade, resulting in more exports. Similarly, countries under WTO agreements are 2 times more likely to trade among themselves than with countries not under WTO agreements.

The rest of the variables, such as GDPs of the exporting and importing country, distance, population exchange rat,e and foreign direct investments have the expected signs and are consistent with theory. Increase in GDP of the exporting country implies a greater capacity to produce domestically, hence more exports, while an increase in GDP of the importing country suggests a higher marginal propensity to import, hence more imports. Distance has the expected negative sign and is statistically significant for the countries in the East Africa region. Longer distance is associated with higher trade costs, thus discouraging trade. A high population is associated with a large market size, which promotes trade. Exchange rate appreciation implies more expensive exports, hence decreases the exports of the exporting country. The results also reveal that high FDI inflows discourage trade within the East African region. The presence of a common ethnic language between the countries in the East Africa region has a positive statistically significant impact on intra-East Africa trade. A common language between two trading partners reduces the cost of communication, and consequently increases exports. The effect of official language was negative, but not statistically significant. The results also show that countries that are neighbouring each other are likely to trade more compared to countries that are not neighbours.

\section{CONCLUSION AND POLICY IMPLICATIONS}

To establish the relationship between infrastructure development and bilateral exports in the East Africa region, the study estimated a gravity model augmented for infrastructure using a panel of 11 countries from 2000 to 2018. The study obtained data on transport and ICT infrastructure index from AfDB socioeconomic database. Bilateral exports data was obtained from WITS of the World Bank, while other explanatory variables were obtained from WDI and CEPII database. The study also introduced control of corruption index and regulatory variables to establish the role of governance and business environment in East Africa's trade. The variable was obtained from the Worldwide Governance Indicators of the World Bank.

3 The coefficient of EAC dummy is expressed as exponent i.e. $\exp (0.45)=1.57$ and WTO, $\exp (0.7)=2.01$ 
Using PPML estimation technique, the study finds that both ICT and transport infrastructure stocks have statistically significant effect on bilateral exports. However, ICT infrastructure has a greater impact on intra-East Africa trade relative to transport infrastructure. Therefore, countries in East Africa can speed up the pace of economic integration through increased investment in ICT and transport infrastructures, which enhances trade.

Based on the findings of this study, countries in the East Africa region would gain more by increasing the stock of ICT infrastructure in the region. Both importing and exporting countries ICT infrastructure have statistically significant effects on intra-East Africa trade. This implies that infrastructure development is important in the regional economic integration process, hence the EAC's efforts to have joint infrastructure projects. In terms of transport infrastructure, the importing country's infrastructure has the greatest impact on exports as compared to the exporting country's transport infrastructure. As a result, in situations of resource scarcity or limited resources for infrastructure investment, more allocations should be given to ICT related infrastructure. In the long-term, countries in the East Africa region should diversify their production to expand more opportunities for trade.

The East African countries would also encourage trade by improving the quality of their institutions. This could be done specifically by reducing corruption in the public sector, while improving on the regulatory quality would encourage more trade in the East Africa region. The presence of regional trade agreements is an important determinant of intra-regional trade. EAC-Partner States trade more amongst themselves due to regional trade agreements under EAC customs union. This signifies the crucial role regional trade agreements play in reducing trade barriers associated with bilateral trade. Similarly, countries under WTO agreements trade more amongst themselves.

\section{REFERENCES}

African Development Bank (2018). The Africa Infrastructure Development Index 2018, AfDB Statistics Department. Available online at https:/www.afdb.org/fileadmin/uploads/afdb/Documents/Publications/ Economic_Brief_-_The_Africa_Infrastructure_Development_Index.pdf.

Alvarez, I., Barbero, J., Rodriguez-Pose, A. \& Zofio, J. L (2017). Does Institutional Quality Matter for Trade? Institutional Conditions in a Sectoral Trade Framework, World Development, 103: 72-87. DOI:10.1016/j.worlddev.2017.10.010.

Anderson, J. E. (1979). A Theoretical Foundation for the Gravity Equation, American Economic Review, 69: 106-116. Retrieved from https://www.jstor.org/stable/1802501?seq=1\&cid=pdf-reference\#references_tab_contents

Anderson, J. E., \& Van Wincoop, E. (2003). Gravity with Gravitas: A Solution to the Border Puzzle, American Economic Review, 93(1): 170-92. DOI: 10.1257/000282803321455214

Bankole, F. O., Osei-Bryson, K. \& Brown, I. (2015). The Impact of Information and Communications Technology Infrastructure and Complementary Factors on Intra-African Trade, Information Technology for Development, 21(1): 12-28. DOI: $10.1080 / 02681102.2013 .832128$

Behar, A. \& Manners, P. (2008). "Logistics and Exports", Mimeo, CSAE: Oxford. Retrieved from https://www. csae.ox.ac.uk/materials/papers/2008-13text.pdf

Behar, A \& Venables, A. J. (2011). Transport Costs and International Trade. In A. de Palma, R. Lindsey, E. Quinet \& R. Vickerman (Eds.), Handbook of Transport Economics. Cheltenham: Edward Elgar. DOI: $10.4337 / 9780857930873$

Bensassi, S., Marquez-Ramos, L., Martinez-Zarzoso, I. \& Suarez-Burguet, C. (2015). Relationship between Logistics Infrastructure and Trade: Evidence from Spanish Regional Exports, Transportation Research Part A, 72: 47-61. DOI:10.1016/j.tra.2014.11.007 
Bonfatti, R. \& Poelhekke, S. (2017). From Mine to Coast: Transport Infrastructure and the Direction of Trade in Developing Countries, Journal of Development Economics, 127: 91-108. DOI: 10.1016/j.jdeveco.2017.03.004

Bougheas, S., Demetriades, P., \& Morgenroth, E. (1999). Infrastructure, Transport Costs and Trade, Journal of International Economics 47: 169-189. DOI: 10.1016/S0022-1996(98)00008-7

Celbis, M. G., Nijkamp, P. \& Jacques, P. (2014). Infrastructure and Trade: A Meta -

Analysis, The Journal of ERSA, 1(1): 25-65. DOI: 10.18335/region.v1i1.25

Clark, X., Dollar, D., \& Micco, A. (2004). Port Efficiency, Maritime Transport Costs, and Bilateral Trade, Journal of Development Economics, 75 (2): 417-450. DOI: 10.3386/w10353

Cosar, A. K. \& Demir, B. (2016). Domestic Road Infrastructure and International Trade: Evidence from Turkey, Journal of Development Economics, 118: 232-244. DOI:10.1016/j.jdeveco.2015.10.001

de Soyres, F. Mulabdic, A. Murray, S. Rocha, N. \& Ruta, M. (2018). How Much Will the Belt and Road Initiative Reduce Trade Costs?. Policy Research Working Paper;No. 8614. World Bank, Washington, DC. World Bank. https://openknowledge.worldbank.org/handle/10986/30582 License: CC BY 3.0 IGO

Donaubauer, J., Glas, A., \& Meyer, B. (2018). Disentangling the Impact of Infrastructure on Trade Using a New Index of Infrastructure, Review of World Economics, 154: 745-784 DOI: 10.1007/s10290-018-0322-8

Djankov, S., Freund, C. L. \& Pham, C. S. (2006). "Trading on Time", World Bank Policy Research Working Paper No. 3909, the World Bank. Retrieved from http://documents.worldbank.org/curated/en/761201468175464382/ Trading-on-time

EAC, (2011a). East African Trade and Transport Facilitation Project: Final Report Arusha,

EAC Secretariat. Retrieved from http://repository.eac.int/handle/11671/1624

EAC, (2011b). $4^{\text {TH }}$ EAC Development Strategy, 2011/12-2015/16. Arusha, Tanzania. Retrieved from https://www. eac.int/documents/category/strategy

Fink, C., A. Mattoo, A., \& Neagu, I.C. (2005). Assessing the Impact of Communication Costs on International Trade, Journal of International Economics, Vol. 67(2), 428-445. DOI: 10.1016/j.jinteco.2004.09.006

Francois, J., \& Manchin, M. (2013). Institutions, Infrastructure and Trade, World Development, 46: 165-175. DOI:10.1016/j.worlddev.2013.02.009

Henckel, T. \& McKibbin, W. (2010). The Economics of Infrastructure in a Globalized World: Issues, Lessons and Future Challenges, The Brookings Institution. Retrieved from https:/www.brookings.edu/wpcontent/ uploads/2016/06/0604_infrastructure_economics_mckibbin.pdf

Hernandez, J. \& Taningco, A. B. (2010). Behind the Border Determinants of Bilateral Trade Flows in East Asia, ARTNeT Working Paper Series, No. 80. Retrieved from https://www.econstor.eu/handle/10419/64311

Ismail, N. W. \& Mahyideen, J. M. (2015). The Impact of Infrastructure on Trade and Economic Growth in Selected Economies in Asia. Asian Development Institute,

Working Paper 553. Retrieved from https://www.adb.org/publications/impact-infrastructure-trade-and-economicgrowth-selected-economies-asia

Limao, N. \& Venables, A. J. (2001). Infrastructure, Geographical Disadvantage, Transport Costs and Trade, World Bank Economic Review, 15: 451-479. https://elibrary.worldbank.org/doi/abs/10.1093/wber/15.3.451

Lin, F. and Fu, D. (2016). Trade, Institution Quality and Income Inequality, World Development, 77, 129-142. DOI: 10.1016/j.worlddev.2015.08.017

Martincus, C. V. \& Blyde, J. (2013). Shaky Roads and Trembling Exports: Assessing theTrade Effects of Domestic Infrastructure using a Natural Experiment, Journal of International Economics, 148-161. DOI: 10.1016/j.jinteco.2012.11.001

Nordas, H., \& Piermartini, R.j. (2004). Infrastructure and Trade: World Trade OrganizationEconomic Research and Statistics Division Staff Working Paper ERSD-2004-04. Retrieved from https://www.wto.org/english/ res_e/reser_e/ersd200404_e.htm

Portugal-Perez, A., \& Wilson, J. S. (2012). Export Performance and Trade Facilitation Reform: Hard and Soft Infrastructure. World Development, 40(7): 1295-1307. DOI: 10.1016/j.worlddev.2011.12.002 
Raychaudhuri, A. \& De, P. (2016). Trade, Infrastructure and Income Inequality in Selected Asian Countries: An Empirical Analysis. In: Roy, M. and Sinha Roy, S., Eds., International Trade and International Finance, Springer, New Delhi, 257-278. https://doi.org/10.1007/978-81-322-2797-7_12

Rehman, F., Noman, A. \& Ding, Y. (2020). Does Infrastructure Increase Exports and Reduce Trade Deficit? Evidence from Selected South Asian Countries using a New Global Infrastructure Index. Journal of Economic Structures, 9(1),1-23. DOI: 10.1186/s40008-020-0183-x.

Sahoo, P., Dash, R. K. \& Nataraj, G. (2010). Infrastructure Development and Economic Growth in China, Institute of Developing Economies, Discussion Paper no. 261, Jetro. Retrieved from https://www.ide.go.jp/English/ Publish/Download/Dp/261.html

Shepherd, B. \& Wilson J. S. (2009). Trade Facilitation in ASEAN Member Countries: Measuring Progress and Assessing Priorities, Journal of Asian Economics, 20(4): 367-383. DOI: 10.1016/j.asieco.2009.03.001

Shepherd, B. (2016). Infrastructure, Trade Facilitation, and Network Connectivity in Sub-Saharan Africa, Journal of African Trade, 3(1): 1-22. DOI:10.1016/j.joat.2017.05.001

Silva, J. S. \& S. Tenreyro (2006). The Log of Gravity, The Review of Economics and Statistics, 88(4): 641-658. DOI: $10.1162 /$ rest.88.4.641

Silva, J. S. \& S. Tenreyro (2011). Further Simulation Evidence on the Performance of the Poisson Pseudo-Maximum Likelihood Estimator, Economics Letters, 112(2): 220-222. DOI: 10.1016/j.econlet.2011.05.008

Tinbergen, J. (1962). Shaping the World Economy: Suggestions for an International Economic Policy. New York: The Twentieth Century Fund.

UNCTAD (2013). Supporting Infrastructure Development to Promote Economic Integration:

The Role of Public and Private Sectors, UNCTAD Secretariat, Geneva, Switzerland. Retrieved from https://unctad. org/meetings/en/SessionalDocuments/cimem6d2_en.pdf

World Bank (2020). World Development Indicators. Accessed at: https://databank.worldbank.org/source/worlddevelopment-indicators. Accessed on $6^{\text {th }}$ August, 2020.

World Trade Organization, (2004). World Trade Report 2004: Exploring Linkage between the Domestic Policy Environment and International Trade, Geneva, Switzerland. DOI: 10.30875/0949bcf3-en

World Trade Organization (2019). Trade Policy Review of the East African Community, WT/TPR/S/384. Retrieved from https://www.wto.org/english/tratop_e/tpr_e/s384_e.pdf

Xing, Z. (2018). The Impacts of Information and Communications Technology and e-Commerce on Bilateral Trade Flows, International Economics and Economic Policy, 15: 565-586. DOI: 10.1007/s10368-017-0375-5

Yu, S., Beugelsdijk, S. \& de Haan, J. (2015). Trade, Trust and the Rule of Law, European Journal of Political Economy, 37: 102-115. DOI:10.1016/j.jpoleco.2014.11.003

Yushkova, E. (2014). Impact of ICT on Trade in Different Technology Groups: Analysis and Implications, International Economics and Economic Policy, 11: 165-177. DOI: 10.1007/s10368-013-0264-5

https://dataportal.opendataforafrica.org/nbyenxf/afdb-socio-economic-database-1960-2020. Accessed on $16^{\text {th }}$ February 2020.

http://www.cepii.fr/cepii/en/bdd_modele/bdd.asp. Accessed on $7^{\text {th }}$ August 2020.

https://wits.worldbank.org/. Accessed on $5^{\text {th }}$ August 2020.

https://data.mendeley.com/datasets . Data set for this study can be accessed using this link. 


\section{APPENDIX}

\section{Appendix A: List of Countries in the East Africa Region}

Table A1: Sample Countries in East Africa

$\begin{array}{ll}\text { Burundi } & \text { Rwanda }^{*} \\ \text { Comoros } & \text { Somalia } \\ \text { Djibouti } & \text { Sudan } \\ \text { Eritrea } & \text { Tanzania* } \\ \text { Ethiopia } & \text { Uganda }^{*} \\ \text { Kenya }^{*} & \end{array}$

*-Refers to East African Community Partner States

\section{Appendix B: Data and Methodology for Generating Infrastructure Composite Index}

Data infrastructure variables were obtained from African Development Bank (AfDB) Socio Economic Database, 1960-2020. According to African Development Bank (2018), transport infrastructure composite index comprises of two indicators:

(a) Total Paved Roads - This is measured in kilometres per 10,000 inhabitants. This acts as a proxy for access to paved road network. It is given by the country's total surface with macadam or bitumen, with concrete or cobblestones.

(b) Total Road Network - This is measured in kilometres per kilometre squared of exploitable land area. It comprises of both paved and non-paved road networks.

The ICT infrastructure composite index comprises of four main indicators:

(a) Total Phone Subscriptions - This is measured as total phone subscriptions per 100 inhabitants in a country. It is given by both fixed telephone lines and mobile cellular telephone subscriptions per year.

(b) Number of Internet Users $\neg-$ This is measured as the total number of internet users per 100 inhabitants. It is given by the total number of internet users from any device (including mobile phones) in the total population per year.

(c) Fixed Broadband Internet Subscribers - This is measured as the total number of fixed broadband internet subscribers per 100 inhabitants. It is given by subscriptions with access to data communications (including internet), exclusive of mobile cellular networks.

(d) International Internet Bandwidth - This is measured by the total capacity of international internet bandwidth in megabits per second (Mbps). It is given by the total capacity of all internet exchanges offering international bandwidth.

In generating an infrastructure index, the first step involves normalizing observed values of each component to take values in the range of 0 and 100 in a given period. The next step is to calculate a composite index of each component. This involves generating weighted average of indicators for each component that has more than one indicator (African Development Bank, 2018). 


\section{Appendix C: Summary Statistics}

Table C1: Summary Statistics for Intra-East Africa Trade

\begin{tabular}{|c|c|c|c|c|}
\hline Variable & Min & Max & Mean & Std. Dev \\
\hline Exports (US\$ ‘000) & 0 & $793,984.4$ & $42,322.5$ & $103,414.9$ \\
\hline GDP i (US\$ Million) & 785 & 87,900 & 19,100 & 19,700 \\
\hline GDP j (US\$ Million) & 785 & 87,900 & 19,100 & 19,700 \\
\hline Distance (weighted) Km & 162.2 & $2,418.3$ & 1,342 & 625.2 \\
\hline ICT Infrastructure $i$ & 0 & 29.94 & 4.89 & 7.21 \\
\hline ICT Infrastructure $j$ & 0 & 29.94 & 4.89 & 7.21 \\
\hline Transport Infrastructure $i$ & 0.48 & 17.57 & 6.90 & 5.50 \\
\hline Transport Infrastructure $j$ & 0.48 & 17.57 & 6.90 & 5.50 \\
\hline Corruption Index $i$ & -1.86 & 0.76 & -0.83 & 0.51 \\
\hline Corruption Index $j$ & -1.86 & 0.76 & -0.83 & 0.51 \\
\hline Regulatory quality $i$ & -2.65 & 0.25 & -1.04 & 0.71 \\
\hline Regulatory quality $j$ & -2.65 & 0.25 & -1.04 & 0.71 \\
\hline Exchange Rate $i$ & 67.32 & $2,263.78$ & 966.86 & 623.95 \\
\hline Foreign Direct Investments i (US\$ Million) & 0.100 & 2,090 & 466 & 520 \\
\hline EAC FTA Agreements & 0 & 1 & 0.74 & 0.44 \\
\hline WTO Trade Agreements & 0 & 1 & 0.50 & 0.50 \\
\hline Official Language & 0 & 1 & 0.60 & 0.49 \\
\hline Ethnic Language & 0 & 1 & 0.34 & 0.47 \\
\hline Contiguity & 0 & 1 & 0.36 & 0.48 \\
\hline
\end{tabular}

Where: $i$ and $j$ refers to the importing and exporting countries respectively, FTA refers to free trade agreements 


\section{RAZVOJ INFRASTRUKTURE, INSTITUCIJA, TRGOVINA UNUTAR REGIONA: SLUČAJ ISTOČNE AFRIKE}

\section{Rezime:}

Ova studija empirijski ispituje vezu između infrastrukturnog fonda ibilateralnih trgovinskih tokova koristeći panel od 11 zemalja istočne Afrike za period od 2000. do 2018. Infrastrukturni gravitacioni model procenjen je korišćenjem ukupnog bilateralnog izvoza za zemlje istočne Afrike. Infrastruktura je razdvojena na infrastrukturu transporta i informaciono-komunikacione tehnologije (IKT). U model su ugrađene dve institucionalne promenljive, kontrola indeksa korupcije i regulatorni kvalitet. Korišćenjem Poasonovog koeficijent pseudo-maksimalne verovatnoće (PPML), rezultati potvrđuju da i IKT i transportna infrastruktura i institucije za kvalitet pozitivno utiču na obim ukupnog bilateralnog izvoza u istočnoj Africi. Međutim, IKT infrastruktura ima veći uticaj na trgovinske tokove u poređenju sa transportnom infrastrukturom. Zbog toga bi trebalo usmeriti više resursa ka povećanju zaliha IKT infrastrukture za podsticanje trgovine i regionalne integracije u istočnoj Africi.

Ključne reči:

Infrastrukturni fond, institucionalni kvalitet, trgovina unutar regiona, Istočna Afrika.

Klasifikacija JEL:

H54, F10, F15 